УДК 811.161.2:165.9

I. С. Беркещук

\title{
ДЕМІНУТИВИ ТА АУГМЕНТАТИВИ - ВИРАЗНИКИ УКРАЇНСЬКОГО МЕНТАЛІТЕТУ
}

Беркещук I. С. Демінутиви та аугментативи - виразники українського менталітету.

У пропонованій розвідці описано та досліджено демінутиви та аугментативи, крізь призму яких відбивається мовна картина світу українців. При усвідомленні, відбиранні та вживанні різних іменників із відмінних, специфічних засобів українці вибирають передусім оцінні, конотативні, а не нейтральні одиниці. 3'ясовано, що на творення цих дериватів впливають власне лінгвальні чинники, соціолінгвальні та психолінгвальні.

Ключові слова: демінутив, аугментатив, емоційно-оцінні лексеми, лінгвальні чинники, соціолінгвальні чинники, психолінгвальні чинники.

Беркещук И. С. Деминутивы и аугментативы - выразители украинского менталитета.

В предлагаемой статье описано и исследовано деминутивы и аугментативы, сквозь призму которых отображается украинская языковая картина мира. При осознании, отборе и употреблении различных существительных со специфических (C) І. С. Беркещук, 2016. 
средств украинцы выбирают в первую очередь оценочные, коннотативные единицы, но не нейтральные. Установлено, что на создание этих дериватов влияют собственно лингвистические факторы, социолингвистические и психолингвистические.

Ключевые слова: деминутив, аугментатив, эмоционально-оценочные лексемы, лингвистические факторы, социолингвистические факторы, психолингвистические факторы. mentality.

Berkeshchuk I. S. Deminutivy and augmentativy - exponents of the Ukrainian

In this paper we described and investigated deminutivy and augmentativy, which is displayed through the lens of Ukrainian language picture of the world. With the knowledge, selection and use of different nouns with specific means of Ukrainians choose in the first evaluation, connotative one, but not neutral. It is established that the creation of these derivatives affect actual linguistic factors, sociolinguistic and psycholinguistic.

According to our observations, the formation of derivatives - deminutyviv and auhmentatyviv - uplyvayut following factors: linguistic, sociolinguistic and psycholinguistic.

During the actual linhistychnymy understand language typological properties that affect the formation of the lexicon, namely suffixal way of creation, which actively influences the creation and deminutyviv auhmentatyviv.

Sociolinguistic factor also leads to the creation of derivatives analyzed. This is facilitated by globalization, development of new technologies and the emergence of related realities, as well as the interaction between languages and between neighboring linguistic formations within society.

Another factor in the creation and deminutyviv, auhmentatyviv is psycholinguistic a way of understanding the collective knowledge of native speakers sociolinguistic conditions. Ukrainian factor due psychology. The new name, something specific and memorable increasingly attracts attention when used in broadcasting.

With awareness, taking and use of different nouns with different specific tools Ukrainian choose, first of all, estimates, connotative unit, not neutral.

Key words: deminutyv, auhmentatyv, emotional and evaluative token, linguistic factors, sociolinguistic factors, psycholinguistic factors.

Останніми роками в сучасному мовознавстві відбувається вивчення мови в тісному зв'язку з людиною, іiі свідомістю, мисленням та духовно-практичною діяльністю.

Опрацьовуючи літературу, пов'язану 3 аналізом та описом українського менталітету, неможливо не звернути увагу на те, що українська мова багата на емоційно-експресивну лексику. Саме тому аналіз таких слів є сьогодні актуальним.

Важливим чинником виникнення певних емоцій $є$ слово, яке може зробити людину щасливою або ж прикро вразити іï.

Для дослідження практичного матеріалу нашої розвідки будемо 
використовувати іменники, оскільки саме іменник «найчіткіше вирізняється 3-поміж інших частин мови завдяки тому, що він відображає передусім субстанційні (зі значенням реальної предметності або зі сприйманим у нашій свідомості таким значенням) об’єкти, а ці матеріальні об'єкти людська свідомість розрізняє найлегше, саме тому межі іменників виявляються досить окресленими» $[3$, с. 47; 4, с. 45]. Як центральна (основна) частина мови іменник становить ядро дериваційної бази українського словотвору, оскільки він має «розвинену морфологічну структуру i великі словотвірні можливості для поповнення словотвірного складу» $[3$, c. 47$]$.

3. Валюх наголошує на тому, що особливості творення дериватів 3 модифікаційними значеннями «демінутивність» та «аугментативність» визначає передусім «лексико-граматичне значення твірного іменника, хоч значною мірою впливають на їхню появу і позамовні чинники, адже місце, де живе людина, територія, простір, які їі оточують і з якими пов'язані життя й трудова діяльність, завжди відіграють важливу роль» $[1$, с. 218$]$.

За нашими спостереженнями, мовна й суспільна практика активно стимулює утворення демінутивів, аугментативні утворення фіксуються рідше, що засвідчує позитивні настрої, доброту, щедру душу українців.

Ті слова нашої мови, які безпосередньо називають певні почуття, настрої або своїм значенням характеризують предмет, особу (на зразок радість, ніжність, сум, ненависть, добрий, хороший, злий) становлять групу емоційної або емоційно-забарвленої лексики. Емоційного забарвлення можуть надавати словам і спеціальні суфікси. Наприклад: рученька, голосочок, коник, хлопчисько, очиці, здоров'ячко, катюга тощо. Сферою вживання таких форм в основному $\epsilon$ художньо-белетристичний, епістолярний, публіцистичний стилі, твори для дітей, фольклор тощо. Звичайно, постійним джерелом поповнення мови іменниками із суфіксами суб'єктивної оцінки є розмовна мова. Слова із суфіксами позитивної оцінки, наприклад жартівливі та іронічно-пестливі, здатні передавати також негативні емоції, наближаючись до іронічно-глузливих.

Продуктивним засобом створення емоційного колориту, яскравості, образності мови є суфікси на позначення негативної (C) I. С. Беркещук, 2016. 


\section{СТРУКТУРА I СЕМАНТИКА МОВНИХ ОДИНИЦЬ}

суб'єктивної оцінки.

Як показали підрахунки, суфікси на позначення негативної суб' єктивної оцінки виступають у значно меншій кількості слів, ніж суфікси позитивної оцінки (приблизно у 8 разів).

Проте діапазон емоційних відтінків, яких здатні надавати іменникам негативно-оцінні суфікси, досить широкий: від слабо виражених відтінків згрубілості, зневажливості, несхвальної оцінки до яскраво вираженої зневаги, іронії, презирства, а в деяких контекстах ненависті, наприклад: вітрище, бабисько, писака, зміюка, п'янюга тощо. Звичайно, самі суфікси не виражають зневажливого, іронічного чи якогось іншого значення -позитивної або негативної оцінки. Тільки сполучаючись із основами слів, суфікс по-новому висвітлює зміст кожного слова. Розгляньмо, яких відтінків набувають слова, поєднуючись із суфіксами -щ- (бабище, хлопчище); -иськ- (плечиська, вовчисько); -аг-, -яг- (мотяга, скупердяга); -юк- (свинюка, шаблюка); -як- (свиняка, иматуряка).

Суфікси -ищ-, -иськ- найпродуктивніші у групі негативнооцінних суфіксів. Найчастіше 3 ними пов'язуються відтінки зневажливого, згрубілого значення слів, аж до яскраво вираженого несхвалення, осуду, презирства: кулачищฺа, басище, язичщще, лігвисько, плечиська.

Кожного разу відтінок емоції у словах із емоційним суфіксом залежить від контексту, від змісту попередніх і наступних речень.

Лексико-граматичний суфікс -ищ- омонімічний 3 лексикосемантичним суфіксом, що утворює абстрактні іменники з відтінком книжності (явище, середовище, становище) і стилістично нейтральні конкретні назви (вогнище, горище, селище). Омонімія цих суфіксів впливає певною мірою на згасання стилістичного забарвлення слів із емоційним суфіксом -ищ-.

Суфікс -яг- надає іменникам відтінку осуду, зневаги, презирства залежно від семантики основи: скупердяга, тесті-скуn'яги.

Відтінок збільшення розміру, обсягу не властивий іменникам iз цим суфіксом. Поєднуючись з іменниковою основою, у значенні якої наявна негативна оцінка, суфікс -яг- посилює емоційний ефект слова аж до створення лайливого відтінку (скупердяга).

Суфікс -юк- має досить широку гаму негативних відтінків: назвам предметів він надає значення збільшення розміру, обсягу, 
якості (холодюка, калюка, грязюка, шаблюка, каменюка), назвам осіб, тварин - значення зневажливості, презирства, інколи лайливого відтінку: зміюка, звірюка, свинюка, сатанюка, тварюка тощо.

Суфікс -юг- пов'язаний із емоційними відтінками зневажливості, презирства (переважно в назвах осіб).

Значення конкретних іменників, назви неживих предметів із суфіксами -юк-, -юг- сприймаються 3 відтінком згрубілості, збільшення розміру, обсягу (палюга, каменюка).

Суфікс -як- надає іменникам відтінку зневажливості, певної згрубілості. Суфікси -юг-, -юк-, -як- можуть виступати як дублетні у складі тієї самої основи, пор.: псюга, псюка, псяка.

Негативну оцінку мають у відповідних контекстах і слова, що вживаються із суфіксами позитивно-оцінними, пор.: голівка і проблемка; коник і цзарик; очиці (дитини) і хитрі очищзі пана.

Емоційних відтінків іронії, гнівного осуду, презирства можуть надавати іменникам суфікси -ик-, -ець-, -ок-, наприклад: попик, царики, купчики, хмарочосик, панок, характерець, народець.

Суфікс -ячк- найчастіше пов'язаний із відтінками іронії, а суфікс -иць- поєднується із основами слів, коли передається презирство, зневажливе ставлення до когось (очииі).

Іронічно-зневажливе забарвлення контексту залежить i від уживання слів із суфіксом -ц-: З’їено м'ясця, крові спито в бойовищах трудних на зорі... (А. Малишко); Лисиия десь м'ясця дістала. Тихесенько прибігла під стіжок - Ум'яла більшенький шматок, А мениий - у сінце сховала (Л. Глібов); С дільце, дядечку, до вас (Л. Глібов).

Суфікси -очк-, -ечк-, -очок-, -ечок- надають іменникам відтінків іронії, неприхованого глузування. Наприклад: Це все через тебе, невістонько!» - промовила Кайдашиха $і$ вдарила до Мотрі кулаком об кулак (І. Нечуй-Левицький).

Рідко вживається для вираження негативної оцінки суфікс -ичк-: Ідіть краще звідси, ідіть, панове покійнички, $і$ не повертайтесь, бо ия Росія може зробити вам велику неприємність (Л. Корнійчук).

Відтінки іронії, зневаги передають і суфікси -оньк-, -еньк-. Наприклад: I рад би Вовк в які ворота скочить, та лишенько йому: куди не поглядить - Усюди Вовченька недоленька морочить, - Хоч сядь та й плач (Л. Глібов); В а д и м. Ого! Так тут мій батенько ๑ І. С. Беркещук, 2016. 
сьогодні глаголить (Л. Дмитерко); Не дуже дави ножем, моє серденько любе, то горщик не буде скавучати, наче собака, щуо зав'язла в тину (I. Нечуй-Левицький).

Нещирість, неприязнь Кайдашихи не приховує «пестливе» звертання до невістки, бо друга частина фрази контрастує з першою, розкриваючи справжнє ставлення свекрухи до невістки.

Суфікси -усь-, -унь- рідко вживаються в контекстах для вираження негативних емоцій. Але при вмілому застосуванні в сатиричних творах іменники з цими суфіксами створюють особливо колоритний емоційний ефект іронії, уїдливого докору тощо.

Звичайно, структурно-семантичні типи емоційно-зниженої лексики не обмежуються лише згаданими суфіксальним або префіксальним типами (побрехенька і підбрехач, перебрехач). Сюди належать також слова із негативним лексичним значенням (дурень, кат); переосмислення прямого значення слова в негативному плані (ситуативна емоційність: собака, гад, акула - про людину); складні слова-іменники (бракороб, людиноненависник); фразеологічні сполуки (прислів'я, приказки: його $і$ довбнею не доб'єш, битий жак - про людину), що може стати предметом окремої розмови.

За нашими спостереженнями, на утворення дериватів демінутивів та аугментативів - упливають такі чинники: власне лінгвальні, соціолінгвальні та психолінгвальні.

Під власне лінгвальними розуміємо типологічні властивості мови, які впливають на формування лексики, а саме суфіксальний спосіб творення, який активно впливає на творення демінутивів та аугментативів.

Соціолінгвальний чинник зумовлює творення аналізованих дериватів. Цьому сприяє глобалізація, розвиток нових технологій та поява пов'язаних із ними реалій, а також взаємодія між сусідніми мовами та між мовними утвореннями всередині соціуму.

Психолінгвальний чинник - спосіб осмислення колективним пізнанням носіїв мови соціолінгвальних умов. Чинник зумовлений психологією українців. Нові найменування, щось специфічне запам'ятовується активніше i привертає увагу при вживанні в мовленні.

При усвідомленні, відбиранні та вживанні різних іменників із відмінних, специфічних засобів українці вибирають передовсім 
оцінні, конотативні, а не нейтральн одиниці.

Отже, емоційно знижена лексика - різновид оцінної лексики, яка є дійсністю не лише думок, а й почуттів людини. Вона допомагає у викритті й активному засудженні всього того, що заважає в суспільному житті. Вважаємо, що менталітет неможливо приховати. Він проявляється в культурі, матеріалізується у способі життя, традиціях, цінностях та нормах поведінки, у мові. Адже кожен мовець формує своє бачення світу не на основі самостійної переробки своїх думок і переживань, а в межах закріпленого в поняттях мови досвіду його мовних предків, що зафіксований у міфах та архетипах. Засвоюючи цей досвід, мовець лише намагається його застосувати й трохи вдосконалити. У процесі пізнання світу створюються й нові поняття, що фіксуються в мові, яка є культурним надбанням, зокрема й демінутивні та аугментативні утворення.

Мова народу - це найбільш універсальне втілення етнічності, підвалина існування культури, історії, традицій, вірувань, побуту i, як результат, - національних відмінностей у сприйнятті світу. Вона виражає національний менталітет, який, переживши століття, зберігає відголоси минулого у приказках, метафорах та інших лінгвальних символах культури.

Уважаємо перспективними подальші дослідження окремих лексико-тематичних груп оцінних субстантивів задля виявлення специфічних рис менталітету та свідомості українців.

\section{Література}

1. Валюх 3. Словотвірна парадигматика іменника в українській мові : [монографія] / 3. Валюх. - Київ - Полтава : АСМI, 2005. - 356 с.

2. Великий тлумачний словник української мови / [уклад. і голов. ред. В. Т. Бусел]. - К., Ірпінь : ВТФ «Перун» 2005. - 1728 с.

3. Вихованець I. Р. Теоретична морфологія української мови : академічна граматика української мови / I. Р. Вихованець, К. Г. Городенська. - К. : Університетське вид-во «Пульсари», 2004. - 398 с.

4. Кубрякова Е. С. Части речи в ономасиологическом освещении/ Е. С. Кубрякова. - М. : Наука, 1978. - 115 с.

Стаття надійшла до редакиії 08.12.2015 p. 